\title{
Pyriproxyfen and the microcephaly epidemic in Brazil - an ecological approach to explore the hypothesis of their association
}

\author{
Maria de Fatima P Militão de Albuquerque', Wayner V de Souza', \\ Antônio da Cruz G Mendes', Tereza M Lyra1', Ricardo AA Ximenes²,3, Thália VB Araújo ${ }^{3}$, \\ Cynthia Braga', Demócrito B Miranda-Filho ${ }^{3}$, Celina MT Martelli', Laura C Rodrigues ${ }^{4}{ }^{+}$ \\ ${ }^{1}$ Fundação Oswaldo Cruz, Centro de Pesquisas Aggeu Magalhães, Departamento de Saúde Coletiva, Recife, PE, Brasil \\ ${ }^{2}$ Universidade Federal de Pernambuco, Recife, PE, Brasil ${ }^{3}$ Universidade de Pernambuco, Recife, PE, Brasil \\ ${ }^{4}$ London School of Hygiene and Tropical Medicine, London, UK
}

The microcephaly epidemic in Brazil generated intense debate regarding its causality, and one hypothesised cause of this epidemic, now recognised as congenital Zika virus syndrome, was the treatment of drinking water tanks with pyriproxyfen to control Aedes aegypti larvae. We present the results of a geographical analysis of the association between the prevalence of microcephaly confirmed by Fenton growth charts and the type of larvicide used in the municipalities that were home to the mothers of the affected newborns in the metropolitan region of Recife in Pernambuco, the state in Brazil where the epidemic was first detected. The overall prevalence of microcephaly was 82 per 10,000 live births in the three municipalities that used the larvicide Bti (Bacillus thuringiensis israelensis) instead of pyriproxyfen, and 69 per 10,000 live births in the eleven municipalities that used pyriproxyfen. The difference was not statistically significant. Our results show that the prevalence of microcephaly was not higher in the areas in which pyriproxyfen was used. In this ecological approach, there was no evidence of a correlation between the use of pyriproxyfen in the municipalities and the microcephaly epidemic.

Key words: Zika virus - microcephaly - pyriproxyfen larvicide

One of the controversies regarding the aetiology of the microcephaly epidemic in Northeast Brazil, which was recognised to be associated with Zika virus infection (Rasmussen et al. 2016, WHO 2016), was the potential harm associated with the use of pyriproxyfen in drinking water tanks as a larvicide against Aedes aegyp$t i$ (ABRASCO 2016). The Brazilian Ministry of Health $(\mathrm{MoH})$ responded to the hypothesised association with the statement, "There are no epidemiological studies showing the association between use of pyriproxyfen and microcephaly". Pyriproxyfen is a pyridine-based broad-spectrum larvicide that functions as an insect growth regulator and is effective against a variety of harmful insects. It was originally used in agricultural pest control (WHO 2008). Pyriproxyfen was approved as a pesticide by the World Health Organisation (WHO) and the Brazilian regulatory agency ANVISA. However, suspicions regarding its safety remained (Bar-Yam et al. 2016, Evans et al. 2016), and the state of Rio Grande do Sul, in Brazil, suspended the use of pyriproxyfen in February 2016 (EBC 2016). A recent review of the literature evaluating the safety of pyriproxyfen revealed a lack of data, preventing an adequate risk assessment of the potential role of pyriproxyfen in the induction of microcephaly (SWETOX 2016).

doi: 10.1590/0074-02760160291

+ Corresponding author: laura.rodrigues@1shtm.ac.uk

Received 30 June 2016

Accepted 14 September 2016
Pernambuco was the first state in Brazil to detect an increase in the number of cases of microcephaly compared to previous years, and it remains the region most affected by the epidemic (Brasil 2016). In Pernambuco, chemical larvicide (pyriproxyfen) or biological larvicide (Bacillus thuringiensis israelensis - Bti) were used in two distinct groups of municipalities, according to the vector control programs (CES 2016).

The current study aimed to explore the possible association between the prevalence of microcephaly, registered during the epidemic, and the use of chemical or biological larvicide in the metropolitan region of Recife (MRR), in Pernambuco state, Brazil.

The MRR is composed of 14 municipalities, with a population of 3,743,854 in 2012 (DATASUS - http://tabnet.datasus.gov.br/cgi/tabcgi.exe?ibge/cnv/poppe.def). According to the State Department of Health data from 2014 and 2015, three municipalities, Recife, Jaboatão and Paulista, used Bti, while the others employed pyriproxyfen (CES 2016). We obtained data regarding notifications of microcephaly from the State Department of Health Surveillance System for the period between 2 August 2015, and 3 April 2016. To define a case of microcephaly, we used Fenton growth curves with a cutoff of -2 standard deviations (SD) below the mean value for newborn head circumference (not the criteria bellow the 3 rd percentile). This is very close, but not exactly the same as the intergrowth standards, which is now recommended to for the assessment of microcephaly (Victora 2016). The number of newborns in the study period was estimated as a proportion (eight months) of the annual number of births in the year 2013 by municipalities (SINASC)/MoH (DATASUS - http://tabnet.datasus.gov.br/ 
TABLE

Prevalence of microcephaly according to the type of larvicide used by municipalities of Recife metropolitan region, Pernambuco, Brazil

\begin{tabular}{|c|c|c|c|}
\hline Municipalities / larvicide & Cases & Newborns & Prevalence per 10,000 \\
\hline \multicolumn{4}{|c|}{ Bacillus thuringiensis israelensis } \\
\hline Recife & 124 & 15,451 & 80.3 \\
\hline Jaboatão & 56 & 6,474 & 86.5 \\
\hline Paulista & 22 & 2,756 & 79.8 \\
\hline Sub-total & 202 & 24,681 & 81.8 \\
\hline \multicolumn{4}{|l|}{ Pyriproxyfen } \\
\hline Olinda & 18 & 4,013 & 44.9 \\
\hline Cabo de Sto. Agostinho & 13 & 2,279 & 57.0 \\
\hline Camaragibe & 14 & 1,572 & 89.1 \\
\hline S Lourenço da Mata & 13 & 1,133 & 114.8 \\
\hline Igarassu & 7 & 1,090 & 64.2 \\
\hline Ipojuca & 14 & 1,066 & 131.3 \\
\hline Abreu e Lima & 4 & 1,021 & 39.2 \\
\hline Moreno & 5 & 543 & 92.0 \\
\hline Itapissuma & 2 & 240 & 83.3 \\
\hline Araçoiaba & 1 & 237 & 42.1 \\
\hline Ilha de Itamaracá & 2 & 217 & 92.0 \\
\hline Sub-total & 93 & 13,412 & 69.3 \\
\hline Total & 295 & 38,093 & 77.4 \\
\hline
\end{tabular}

$\chi^{2}=1.61 ; \mathrm{df}=1 ; \mathrm{p}=0.21$

cgi/deftohtm.exe?sinasc/cnv/nvpe.def). This number was used as the denominator to calculate the prevalence rates according to the mother's municipality of residence. We tested the difference in the prevalence of microcephaly for the two groups of municipalities: those exposed to pyriproxyfen versus those not exposed.

We calculated the risk ratio and $95 \%$ confidence interval $(\mathrm{CI})$ with a significance level given by the $\mathrm{c}^{2}$ test with Yates correction. During the study period, there were 719 reported cases, with 295 (41\%) cases confirmed by the Fenton criteria.

Table presents, for each municipality, the proportion of newborns with microcephaly born to mother who were residents of that municipality and indicates whether pyriproxyfen was used in the drinking water tanks in that municipality. The three municipalities in which Bti was used had an overall prevalence of microcephaly of 82 per 10,000 live births, which was not statistically significantly different from the prevalence of 69 per 10,000 live births in the 11 municipalities that utilised pyriproxyfen. The risk ratio obtained was 0.85 (95\% CI, $0.66-1.08 ; p=0.21)$. Figure displays the spatial distribution of microcephaly prevalence per 10,000 live births according to the municipalities of the MRR.

Our results show that the prevalence of microcephaly was not higher in the areas in which pyriproxyfen was used. In this ecological approach, there was no evidence of a correlation between the use of this larvicide in the municipalities and the epidemic of microcephaly. This study is relevant to document the lack of an association, and we hope it is also a good example of the use of routine data to test a hypothesis. One limitation of this study is that the spatial units are large and populous. There may be a certain degree of heterogeneity in the vector control activities at the neighbourhood and house levels. Nevertheless, only one type of larvicide was used in each municipality during the reference period.

Considering that this was an ecological study, we do not have information regarding exposure on disaggregated levels. We compared areas exposed to pyriproxyfen to areas not exposed to pyriproxyfen to test if there was an association between pyriproxyfen and microcephaly at the ecological level. However, our findings do not invalidate the argument that improvements in environmental management to prevent and control disease may be a better choice than the widespread use of larvicide in drinking water for vector control, nor do they exclude other potential toxicities of pyriproxyfen (ABRASCO 2016). In addition, it should be noted that the mosquito vector control strategies during the past three decades, mainly based on chemical insecticides and larvicides, have proven ineffective (Regis et al. 2014, Augusto et al. 2016). Moreover, it is necessary to investigate other potential toxicities of pyriproxyfen. Despite approval from regulatory agencies (WHO 2006), further research may be needed to exclude other negative health outcomes, since during the Zika epidemic (and the potential emergence of other arboviruses), this product 


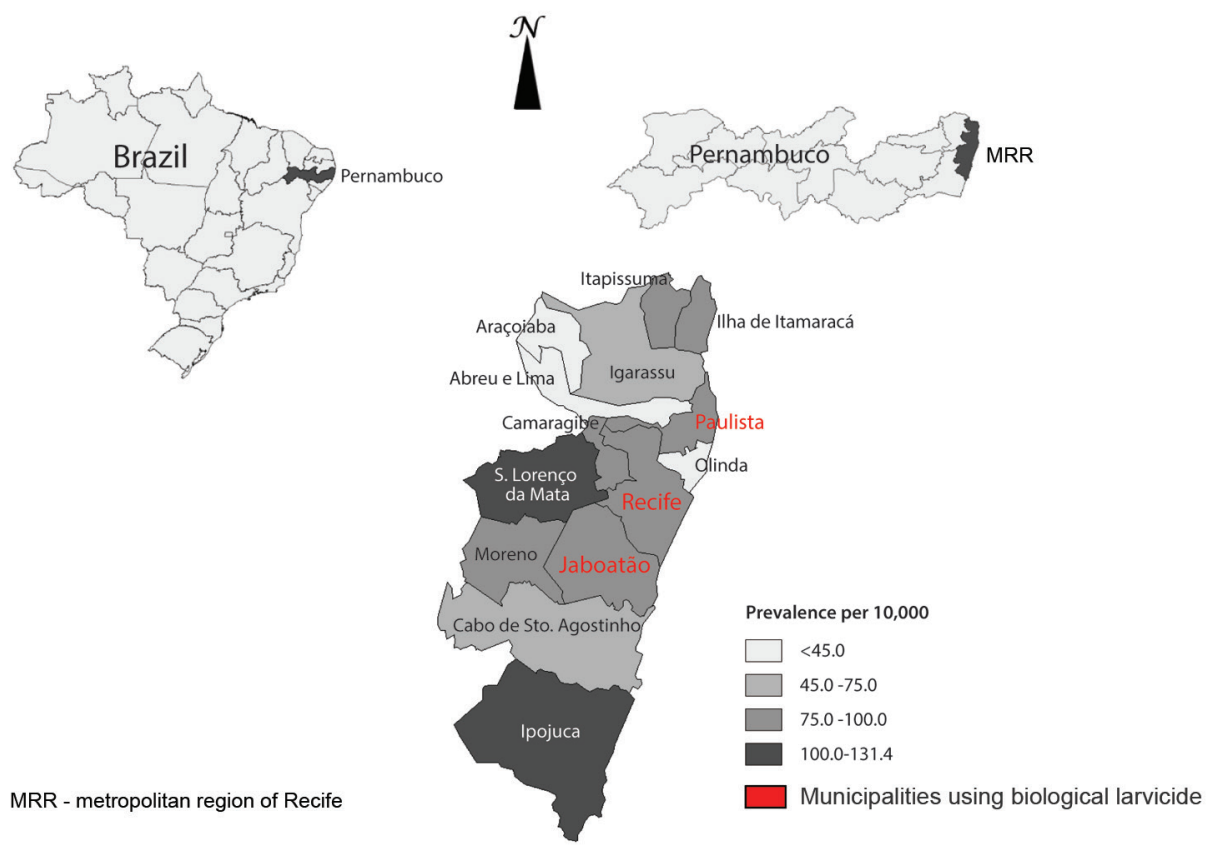

Prevalence of microcephaly per 10,000 live births according to municipalities of Recife metropolitan region, Pernambuco, Brazil.

might be applied even more widely to drinking water for vector control. We emphasise that our findings seem timely because the analysis was performed in a region in which the microcephaly epidemic was most severe, and for which information was available on the use of chemical or biological larvicide by municipalities.

\section{REFERENCES}

ABRASCO - Associação Brasileira de Saúde Coletiva. Nota técnica sobre microcefalia e doenças vetoriais relacionadas ao Aedes aegypti: os perigos das abordagens com larvicidas e nebulizações químicas - fumacê [Internet]. 2016 [cited 2016 May 4]. Available from: https:// www.abrasco.org.br/site/2016/02/nota-tecnica-sobre-microcefaliae-doencas-vetoriais-relacionadas-ao-aedes-aegypti-os-perigos-dasabordagens-com-larvicidas-e-nebulizacoes-quimicas-fumace/.

Augusto LG, Gurgel AM, Costa AM, Diderichsen F, Lacaz FA, ParraHenao G, et al. Aedes aegypti control in Brazil. Lancet. 2016; 387(10023): 1052-3.

Bar-Yam Y, Evans D, Parens R, Morales AJ, Nijhout F. Is Zika the cause of microcephaly? Status Report June 22, 2016. New England Complex Systems Institute (June 22, 2016). 2016. Available from: http://necsi.edu/research/social/pandemics/statusreport.

Brasil - Ministério da Saúde do Brasil. Microcefalia: Ministério da Saúde confirma 1.271 casos no país. 2016. Available from: http://portalsaude.saude.gov.br/index.php/cidadao/principal/ agencia-saude/23534-microcefalia-ministerio-da-saude-confirma-1-271-casos-no-pais.

CES - Conselho Estadual de Saúde de Pernambuco. Grupo de trabalho se reúne para discutir o uso do pyriproxyfen no combate ao $A e$ des Aegypti [Internet]. 2016 [cited 2016 April 25]. Available from: http://www.ces.saude.pe.gov.br/grupo-de-trabalho-se-reune-paradiscutir-o-uso-do-pyriproxyfen-no-combate-ao-aedesaegypti/.

EBC - Empresa Brasil de Comunicação S/A - Agência Brasil. RS suspende uso de larvicida Pyriproxyfen no combate ao mosquito $A e$ - des [Internet]. 2016 [cited 2016 April 25]. Available from: http:// agenciabrasil.ebc.com.br/geral/noticia/2016-02/rs-suspende-larvicidapyriproxyfen-usado-em-caixas-dagua-para-combater-aedes.

Evans D, Nijhout F, Parens R, Morales AJ, Bar-Yam Y. A possible link between pyriproxyfen and microcephaly [Internet]. Report No biorxiv; 048538v1. 2016 [cited 2016 May 4]. Available from: http://biorxiv.org/lookup/doi/10.1101/048538.

Rasmussen SA, Jamieson DJ, Honein MA, Petersen LR. Zika virus and birth defects - Reviewing the evidence for causality. N Engl J Med. 2016; 374: 1981-7.

Regis LN, Acioli RV, Silveira Jr JC, Melo-Santos MAV, Cunha MCS, Souza F, et al. Characterization of the spatial and temporal dynamics of the dengue vector population established in urban areas of Fernando de Noronha, a Brazilian oceanic island. Acta Trop. 2014; 137: 80-7.

SWETOX - Swedish Toxicology Science Research Center. Pyriproxyfen and microcephaly: an investigation of potential ties to the ongoing “Zika epidemic". Södertälje: 2016. [cited 2016 May 4]. Available from: http://swetox.se/wpcontent/uploads/2016/03/ppf-zika.pdf.

Victora CG, Schuler-Faccini L, Matijasevich A, Ribeiro E, Pessoa A, Barros FC. Microcephaly in Brazil: how to interpret reported numbers? Lancet. 2016; 387(10019): 621-4.

WHO - World Health Organization. Guidelines for drinking-water quality: second addendum to third edition. 2008. Available from: http://www.who.int/water_sanitation_health/dwq/secondaddendum20081119.pdf.

WHO - World Health Organization. Specifications for public health pesticides. Pyriproxyfen technical material. 2006. Available from: http://www.who.int/whopes/quality/en/pyriproxyfen eval_specs_WHO_jul2006.pdf.

WHO - World Health Organization. Zika virus microcephaly and guillain-barré syndrome. Situation Report. 2016. Available from: http://apps.who.int/iris/bitstream/10665/204718/1/ zikasitrep_31Mar2016_eng.pdf. 